\title{
Money laundering and the shadow economy in Kazakhstan
}

Article

Accepted Version

Niyatullayev, N. and Almond, P. (2014) Money laundering and the shadow economy in Kazakhstan. Journal of Money Laundering Control, 17 (2). pp. 128-140. ISSN 1368-5201 doi: https://doi.org/10.1108/JMLC-05-2013-0015 Available at https://centaur.reading.ac.uk/37966/

It is advisable to refer to the publisher's version if you intend to cite from the work. See Guidance on citing.

Published version at: http://dx.doi.org/10.1108/JMLC-05-2013-0015

To link to this article DOI: http://dx.doi.org/10.1108/JMLC-05-2013-0015

Publisher: Emerald Insight

All outputs in CentAUR are protected by Intellectual Property Rights law, including copyright law. Copyright and IPR is retained by the creators or other copyright holders. Terms and conditions for use of this material are defined in the End User Agreement.

\section{www.reading.ac.uk/centaur}

\section{CentAUR}

Central Archive at the University of Reading

Reading's research outputs online 


\section{Money Laundering and the Shadow Economy in Kazakhstan}

\section{Introduction}

The criminalisation of money laundering has emerged to become a new norm of international law and a core component of the governance of the world economy during the last twenty years. This development was given added impetus following the 9/11 terrorist attacks in the USA and subsequent attacks in the UK and Europe, since when the focus of money laundering measures has been redirected towards the financing of terrorist activities (Alldridge 2008; Levi 2002). It remains a key area of negotiation between the nations of the West and those of the developing world, and has prompted a significant degree of harmonisation between national jurisdictions, as well as points of difference in policy and practice. And while public and political concern over the threat posed by the illicit legalisation of criminal assets remains significant, there are areas of uncertainty around this issue which impact in particular on developing nations. In particular, it has proved difficult to clearly define the social and economic rationale for the legal control of money laundering in these jurisdictions.

The movement from an economic rationale, which legitimises the control of all laundered money, to a crime rationale, which emphasises the control only of the proceeds of certain high-risk areas of criminality, arguably results in a 'blanket' approach to criminalisation that can fail to address the local concerns of developing countries. There are significant financial costs associated with the control of money laundering, associated with both the costs to government of establishing the national and international organizations needed to fight it, and with the compliance costs that accrue to businesses and entrepreneurs who are subject to these controls (Geiger and Wuensch 2007; Harvey 2004; Reuter and Truman 2004). In particular, these costs are problematic for developing nations to bear, being almost as great as the direct costs associated with the fight against illegal enterprise and smuggling. Despite this, action to combat money laundering remains necessary due to the facilitative effect that those proceeds have in terms of organised criminality (Levi 2002: 183-4). An examination of the circumstances surrounding the introduction of money laundering controls in one developing country, Kazakhstan, will highlight some of the problems with, and alternatives to, the blanket criminalisation of money 
laundering activities. Experience in Kazakhstan suggests that approaches such as an 'amnesty' on some forms of illegally-acquired capital can offset some of the potentially negative effects of money laundering, allowing for the root causes of the problem, namely predicate offending, to be tackled with more energy and resource.

\section{The Wider Context of Money Laundering Controls}

The international money laundering control system has its modern antecedents ${ }^{1}$ in the early efforts at national controls instituted in the USA by the Bank Secrecy Act of 1970 (Levi and Reuter 2006: 296), and elsewhere. The 1970 Act required that all US banks provide a report to the Treasury on all financial transactions conducted in cash and exceeding $\$ 10,000$ USD in value. This was a regulatory measure designed to prevent tax evasion; as such, the rationale behind its introduction was primarily economic in nature and so the law sought to control the effects of illicit money rather than the conduct that generated it. And this outlook informed the approach taken by the emergent international money laundering control system, in the form of the Financial Action Task Force on Money Laundering (FATF), established in July 1989 at the G-7 Paris Economic Forum. This body assesses the effectiveness of national money laundering controls, and establishes model legislation and standards for its members. ${ }^{2}$ Official statements made by FATF about the rationale underpinning the money laundering agenda have emphasised the corrosive effects of the proceeds of money laundering upon developing and established economies (FATF 2011: 9-10; Alldridge 2008), and so roots the new regulatory system in the need to control threats to the integrity of the international financial system. ${ }^{3}$ The FATF's emphasis on economic harm also reflects concerns over the social effects of money laundering on GDP, standards of living, and mortality and literacy rates (FATF 2011: 9).

The problem is that this rationale remains both empirically uncertain (Cuéllar 2003; Levi and Reuter 2006) and politically questionable; anti-money laundering policies arguably involve developed economies imposing restrictive controls onto developing

\footnotetext{
${ }^{1}$ Older precedents can be traced back to the actions of Chinese traders in concealing assets several thousand years ago (Seagrave 1995), and to the American mafia's legitimization of the proceeds of the illicit alcohol trade during the prohibition era (Haller 1990; Levi and Reuter 2006).

${ }^{2}$ Currently, the FATF has a membership consisting of 34 national governments and two regional organisations (the EU and the Gulf Cooperation Council). A number of organisations also have observer status, such as the IMF, the European Central Bank, and the World Bank.

${ }^{3}$ See www.fatf-gafi.org/pages/aboutus/ and www.fatf-gafi.org/pages/faq/moneylaundering/
} 
ones in a manner which is 'empirically dubious, over-inclusive, and paternalistic' (Alldridge 2008: 447), and which can place additional financial limits onto developing economies already damaged by the movement of assets into the illicit economy in the first place. By emphasising the consequences of illicit financial practices, this approach treats all laundered money in the same way regardless of origin, and thus leads to enforcement approaches that emphasise procedural compliance and cast the net of monitoring and control widely, placing significant burdens onto national enforcement and implementation bodies; the cost of the anti-money laundering regime in the USA alone was estimated in 2003 at around \$7 billion USD (Reuter and Truman 2004). It is also entirely legitimate to query whether the funds that are being laundered would still merit criminalisation if they were being used in such a way as to produce more good than harm? Might it not make sense to permit a flow of money into a national economic system if such a measure would assist in state restructuring and lead to better social outcomes?

This economic rationale has also been undermined by the subsequent shift in attention on the part of national and international enforcement and money laundering control regimes, away from a regulatory approach to finance and towards the policing of financial activities which are prioritised not for their macro-economic impact, but because they relate to socially dangerous criminal activities that constitute political problems for Western governments (Garland 2001; Simon 2007). By the mid-1980s, the 'war on drugs' in the USA had refocused money laundering controls onto tackling the processing of cash derived from drug dealing and smuggling (Levi 2002: 186; Levi and Reuter 2006: 296); 'following the money' was seen as an effective way to disrupt these criminal activities. This focus on drug proceeds can be seen at an international level in the terms of the United Nations Convention against Illicit Traffic in Narcotic Drugs and Psychotropic Substances 1988 (the Vienna Convention). Similarly, the post-9/11 era has seen a new emphasis on terrorist financing, in order to both limit the capacity of terrorists to act and to inculpate those who support or facilitate that action (Levi and Gilmore 2002).

The systems of control over money laundering that have emerged in the majority of countries since then have focused on the legalization of money and property acquired through an ever-widening array of predicate crimes; the FATF's core 
recommendation in this area is that [C]ountries should apply the crime of money laundering to all serious offences, with a view to including the widest range of predicate offences' (FATF 2012: 34). This creates an extended international mechanism of crime control which serves two purposes; the prevention of criminal activity via indirect enforcement (particularly in areas where direct enforcement is difficult), and the regulation of the internal integrity of the market. The former rationale reflects the growth of pluralised, partnership-oriented, devolved models of crime control (Garland 2001), and explains the emphasis on including all serious predicate offences; the latter explains the imposition of restrictive technical requirements (such as customer due diligence) and systems of reporting that apply to all forms of transaction, whether legitimate, illegitimate, or illegal, in order to establish ground-rules for entry and activity in the marketplace (Braithwaite 2008). Both sides of this coin are 'intended to limit criminal access to the financial system' (Levi and Reuter 2006: 297).

The global system of standard-setting and monitoring ensures that emergent markets are secure arenas for investment and commercial activity; in this sense, it is an engine of globalisation (Alldridge 2008). National governments have moved away from traditional law-enforcement structures as a way of fulfilling these roles, and towards the institution of systems of monitoring that incorporate analytical methodologies and financial intelligence as means of monitoring financial flows and identifying assets linked to crime. This is facilitated via the establishment of statelevel financial monitoring institutions such as the USA's Financial Crimes Enforcement Network (FinCEN), an agency within the Department of Treasury, and the political leverage applied by supranational organisations like FATF. This organisation compiled an annual 'blacklist' of countries that were not conducting sufficiently comprehensive measures to prevent the laundering of criminal assets. This led to the international dissemination of an inclusive model of money laundering which encompasses many forms of financial activity, and does not necessarily limit itself to any particular manifestations of predicate offending. This can be intrusive and distort state sovereignty and state-individual relations (Alldridge 2008; Levi and Reuter 2006). Methods of fighting money laundering often conflict with generally accepted legal principles such as the presumption of innocence and banking secrecy. Little remains known about the effectiveness of this system, or about the 
scale of the problem that it seeks to address.

All of these consequences are tolerable so long as there is an understanding that the system works in the interests of the societies within which it applies; that it is reducing the ability of criminal actors to engage in the illegal, harmful activities that give rise to illicit funds, and that it is improving the capacity of national economic systems to deliver benefits to citizens (via security, stability, and wealth). The problem comes when it is applied in the context of a society where the sheer extent of the illicit economy is so great that the national economy is seriously compromised. A country that is in this position might benefit from the development of laws to prevent the distortion of the economy, and thus acquire the legitimacy required in order to play a part in the world market. But establishing rigid firewalls against the legalization of illicit property while it constitutes a large proportion of the national economy may narrow that country's capacity to redevelop its economic system. As such, there is a case for augmenting the use of criminalising anti-money laundering measures with other approaches so that the restrictiveness of the former acts to the benefit, and not the detriment, of the national economic system. This case will be demonstrated via reference to one particular national jurisdiction, Kazakhstan.

\section{The Shadow Economy in the Republics of the former Soviet Union}

After the collapse of the USSR and Europe's Eastern Bloc in the early 1990s, the newly independent Republics faced many tasks of infrastructure reconstruction and social modernisation. This included legal redevelopment, as these new States required legal systems that could address the realities of the modern international community, the creation of which would benefit from the accrued experience of more established western legal systems. In countries such as Kazakhstan, the desire to learn and adopt from abroad was explicit: '[R]esolving these issues is not possible without basic research which, in turn, requires a[n]... appeal to foreign experience of legal construction, which has proved its effectiveness and viability, with a view to its possible borrowing' (Dzhekebaev 2001: 3). The reform of domestic legislation to fit a 'western-style' model was undertaken, along with the adoption of the legislative practices of overseas legal institutions and the introduction of new regulations into newly-reconstructed areas of social life. In many cases, in countries like Kazakhstan, this was done before the problems the law was intended to address had been fully 
experienced, in order to ensure compliance with international requirements. While the development of new legislative frameworks in countries like Kazakhstan was achieved with some success, there were areas, such as money laundering law, where social structures were simply not ready to implement the necessary changes.

Bringing Kazakh domestic money laundering laws into compliance with international legal standards involved the introduction, via the new Criminal Code of Kazakhstan in 1997, of new offences to control the flow of assets in the private economic sphere. Not only did no criminal offences of this type exist prior to this time, but the bureaucratic, centrally-managed command-control economy of the Soviet era, coupled with the prevailing collectivist cultural and legal traditions of the region (Kim and Pridemore 2006; Nichols 2001: 912; Olcott 2010: 60), meant that there was little experience or capacity to underpin the regulation of private economic transactions (Eilat and Zinnes 2002: 1236). Like elsewhere in the former Soviet Union (Holmes 2009: 270; Kim and Pridemore 2005; 2006), the post-transition period in Kazakhstan saw an upsurge in acquisitive offending as the economic system was restructured along free-market lines, a process pursued more aggressively here than elsewhere (Alam and Banerji 2000). Kazakhstan was propelled swiftly into independence, with little time for preparation (Olcott 2010: 16); the changing social, institutional and legal structures of this period created 'institutional vacuums' in the new systems of regulation which private actors were able to capitalise on in order to withdraw large sums of money and property from the legitimate economy (Holmes 2009; Iwasaki and Suzuki 2007: 400-1; Nichols 2001: 908-10). At the same time, a population that had suffered many years of material deprivation under communism was suddenly presented with opportunities to acquire material wealth, and a shift away from the certainties of the communist era allowed for a new moral ideology of personal enrichment at all costs to flourish (Olcott 2010: 60). Economic redevelopment, socialstructural change, and rapid privatisation created structural gaps in regulatory systems that allow the shadow economy to develop (Eilat and Zinnes 2002: 1236) as an endemic feature of the new market system from the outset.

The result of these transitional difficulties was the development of a large, entrenched, shadow economy in emergent post-Soviet nations like Kazakhstan. While difficulties remain in accurately determining the parameters of the shadow 
economy, some key elements have been identified: 1) the informal economy, including the otherwise legal proceeds of the supply of goods and services which are concealed for taxation purposes and so not recorded in official statistics; 2) the unregulated economy, including the proceeds of activities that bypass reporting, licensing, or other official requirements; 3) the fictitious economy, including the nondeclarable proceeds of offences such as theft, bribery, and fraud related to the receipt and transfer of money; and 4) the underground economy, including the economic proceeds of criminal activities prohibited by the law, such as drug and weapon smuggling (Eilat and Zinnes 2002; Schneider and Enste 2000). The unifying definitional feature is that all of these activities are outside the scope of the taxation and budgetary systems, and thus do not feature in the GDP figures for the national economy. As such, the shadow economy is broader in scope than simply the income derived from the kinds of criminal activity that the international money laundering system has prioritised.

A five-step model for this process of development in Kazakhstan has been suggested (Darimbetov and Spanov 2001), beginning with an emergent conflict during the mid-1980s between a new business sector and government agencies over reform of the latter's monopolistic economic controls. Second, between 1989 and 1992, as the Soviet Union collapsed, the government lost control of statesubsidised industries as its economic management capacity was reduced; private and criminal enterprises were able to acquire control of these industries and their assets cheaply. Third, after independence in 1993, this process of privatization, which had been unofficial, became a formal policy process, accelerating the passing of former public assets into private (and/or clandestine) hands (Olcott 2010: 135). Fourth, between 1993 and 1998, this illegally acquired wealth began to filter back into the legitimate economy in the form of foreign capital investment, assisted by a sharply rise in corruption in the public sector. Finally, since 1999, Kazakhstan has seen both the creation of the preconditions for legitimate economic growth, and the expansion of the shadow economy via smuggling, organised crime, and double-entry bookkeeping within industry, prompting the development of measures to address the issue of illegitimate capital (Darimbetov and Spanov 2001: 46-7).

The effects of this shadow economy can be seen in almost all spheres of society 
(Nichols 2001). In the late 1990s, the annual volume of shadow capital transaction within Kazakhstan was estimated at $\$ 6-7$ billion dollars, involving up to $15 \%$ of the economically active population of the country in activities that bypass the taxation, budgetary, and social security systems of the state (Kulekeev 1997). Eilat and Zinnes (2002: 1239) estimated the shadow economy of Kazakhstan to be equivalent to $27 \%$ of national GDP, while Schneider (2003: 27 ) put this at $42.2 \%$ in 2001 , occupying $34 \%$ of the working-age labour force. Government sources in Kazakhstan estimate that the share of shadow economy in Kazakhstan over the ten years has decreased from 30 to 20 per cent of GDP, equivalent to 35 trillion $^{4}$ Kazakh tenge $(\mathrm{KZT})$, or $\$ 5$ billion USD. As such, the legalisation of illicit capital is a more pervasive issue in Kazakhstan than might be the case in western countries as it encompasses such a large amount of illicit commercial activity (and proceeds stemming from fraud and the abuse of positions of public authority) in addition to the proceeds of crimes like drug smuggling. And so while international efforts at money laundering control have focused on the latter (Levi and Gilmore 2002), in a country like Kazakhstan, the issue is not simply one of crime control, but also one of reconstituting the market and reclaiming a large proportion of the economic activity of the nation. As such, it may be argued that overtly criminalising approach to money laundering control may address only one part of a much larger problem; there is room for the pursuit of 'market-constituting' (Braithwaite 2008) strategies alongside this crime-control paradigm.

\section{Kazakhstan's response to money laundering (I): Criminalisation}

Many different steps have been taken by the government of Kazakhstan to tackle the shadow economy by enhancing the attractiveness of legitimate business activity, including the simplification of the procedures for the registration of natural persons and legal entities for business purposes, and the reform of the tax system and the reduction of regulatory burdens. Along with the general improvement of the climate for law-abiding business in the country, a key role has been played by law reforms which aimed to criminalise money laundering. Central to this was the adoption of the new Criminal Code of Kazakhstan on July 16, 1997, which fundamentally differed from the old 1959 Code of the Kazakh SSR. This previous legislation did not meet

\footnotetext{
${ }^{4}$ http://www.zakon.kz/4468735-dolja-tenevojj-jekonomiki-v-kazakhstane.html
} 
the requirements of the modern international community in terms of criminalising harmful commercial conduct; the new Criminal Code addressed money laundering issues, as well as providing a more structured legal framework that reflected the values enshrined in the 1995 Constitution of Kazakhstan (Dzhekebaev 2001). Its provisions came into force on January 1, 1998.

Section 193 of the Criminal Code sets out the basis of criminal responsibility for the legalization of illicit income, making it an offence to engage in: '[t]he performance of financial transactions and other transactions with monetary funds or other property acquired by illegal means, as well as the use of such funds or other property for entrepreneurial or other economic activity. The offence encompasses a wide range of asset transfers which might provide a route to the legitimisation of illegallyacquired assets, and so fulfils the international requirements laid down in the UN Convention for the Suppression of the Terrorism Financing of 1999. The terms of this offence were significantly broader than the laws of most other national jurisdictions, in that the term 'illegal' used here was capable of including the proceeds of administrative offences and civil wrongs as well as the proceeds of crime per se. This meant that Kazakh law was not compliant with wider international standards. However, the Supreme Court of the Republic of Kazakhstan issued a Normative Resolution on June 18, 2004 which specified that '[t]he grounds of criminal responsibility according to Article 193 of the Criminal Code is the legalization of money or other property derived only from illegal activities (smuggling, weapon trafficking, drugs, embezzlement, tax evasion, etc.)' (para. 10). By defining the predicate basis of money laundering liability in this way, the Supreme Court of Kazakhstan interpreted domestic law so as to conform to the narrower approach taken in international legal instruments, limiting the scope of inquiry to the proceeds of 'core' offences.

As well as defining the terms of the offence, the second and third elements of Article 193 proscribes a maximum penalty for its breach of up to three years imprisonment, and set out two categories of aggravating features which exacerbate the seriousness of the offence. The lesser category includes offences that are committed: a) by a group of persons by prior agreement; b) more than once; and c) by a person using their official position. The more serious category includes offences committed: a) by 
a person authorized to perform public functions, if they involve the use of his official position; b) by an organized group; and c) by a large-scale criminal organization. While there is no minimum threshold in terms of the amount of laundered money that must be involved in order to lead to criminal liability, the involvement of a sum greater than ten thousand times the monthly specified index rate ${ }^{5}$ (approximately $\$ 100,000$ USD) will lead to an aggravated form of liability carrying a maximum penalty of seven years imprisonment. This initial process of criminalisation was not wholly effective; Article 193 has been characterised as constituting 'empty' legislation (Tang and $\mathrm{Ai}$ 2010: 216) on the basis of a practical lack of commitment to implementation, and the lack of a financial intelligence unit to coordinate this process. Further, the IMF in 2004 observed that, while positive progress had been made towards reform of the financial sector in relation to money laundering, the existing legal framework did not meet international standards (IMF 2004: 21).

Effective compliance with FATF and other international recommendations required further reform, and this came in the form of a subsequent Act of the Republic of Kazakhstan 'On counteracting the legalization (laundering) of illegally funds, and financing terrorism', adopted on August 28, 2009 and implemented on March 9, 2010. This Act was intended to define the legal basis of state efforts to counteract the laundering of the proceeds of crime and the role of non-state entities in financial monitoring. It specifies the range of private bodies that must engage in monitoring processes (Art. 3), and the nature of the transactions that must be monitored, including many of the generally-recognised phenomena associated with moneylaundering (Art. 4); this includes both transactions defined as 'suspicious', but also all financial transactions of certain forms above a threshold value level. It sets out the due diligence requirements (Arts. 5-9) and recordkeeping and internal controls required (Arts. 10-12), and the reporting mechanisms for the notification and nonprocessing of suspicious transactions (Arts. 13-14). Finally, it sets out the responsibilities of an Authorized Body (Arts. 16-18) which will coordinate and lead the national efforts at money laundering control (this role is fulfilled by the Financial Monitoring Committee of the Ministry of Finance of the Republic of Kazakhstan). This

\footnotetext{
${ }^{5}$ The monthly index rate is a ratio, set with reference to the annual budget, for the calculation of penalties, taxes and other charges in accordance with the laws of the Republic of Kazakhstan. Currently, the monthly index is $1618 \mathrm{KZT}$ (approximately $\$ 10.79$ USD). As such, the aggravating level specified by Article 193 is equivalent to 16.18 million KZT (\$107,900 USD). In November 2011 this level was adjusted to 20,000 times the monthly index rate.
} 
legislation brought Kazakh law broadly into line with international requirements, although some areas of concern remain, such as the manageability of the nonsuspicious transaction reporting rules, and the suitability of having the Authorized Body located within the Ministry of Finance. In terms of enforcement, in the first seven years of the anti-money laundering regime, only fifty cases were ever registered; between 2006 and 2011, this increased to 531 cases registered.

\section{Kazakhstan's response to money laundering (II): Amnesty}

The legal reforms outlined above focus on bringing Kazakh law into compliance with international laws governing the processing of the proceeds of crime. As discussed previously, however, this approach focuses attention onto one element of a much wider problem, and by imposing criminal controls onto the processing of illegallyacquired finances, validates the security and integrity of the national economic system by excluding illegitimate finance, thus facilitating investment (Alldridge 2008 : 448-450). This is a market-constituting effect, in that it enforces the boundaries of the marketplace and the limits of acceptable commercial conduct, protecting other market actors (Braithwaite 2008). One of the problems with this approach is that it is designed to exclude the proceeds of unacceptable forms of criminal conduct and so creates a rigid 'firewall' between those proceeds and the mainstream economy. But in a country like Kazakhstan, where a significant proportion of the economy is in 'shadow', and not necessarily a result of criminal activity, this firewall has the effect of limiting the ability of the state to 'reclaim' those assets for investment in lawful commercial enterprises, and thus for official declaration and taxation. If the predicate conduct giving rise to the proceeds is not itself a serious criminal matter, then criminalising the subsequent use of those proceeds significantly widens the criminal law into an area where the putative benefits of control are much harder to demonstrate (Alldridge 2008: 451). As such, there is a case to be made for the development of state responses that better facilitate the reclamation of illicit assets, and thus economic development processes.

While most countries of the former Soviet Union experienced very high levels of illicit capital accumulation during the initial period of independence, most have subsequently treated those existing illicit funds with relative indifference, legislating in relation to future laundering activities while leaving the bulk of the illicit economy 
intact, and often choosing to 'adopt but not enforce' anti-money laundering laws (Tang and Ai 2010). There is rarely any focused strategic plan put in place to legitimize these funds. In this regard, however, Kazakhstan is somewhat different from its neighbours as it has pursued a dual approach, both criminalising money laundering (as above) and facilitating the legalisation of funds by declaring two amnesties allowing for the voluntary declaration of illicit proceeds, in 2001 and again in 2006-2007. At this point in time Kazakhstan, like many other developing countries, was experiencing a lack of investment funds to facilitate the development of its economic infrastructure; there was a clear economic benefit to be gained from bringing a proportion of the shadow economy into the mainstream by making 'opponents' free to invest in legitimate fields. At the same time, the state lacked the capacity to make a significant dent in the existing problem of the illegitimate economy via a criminal enforcement approach; an amnesty represented an approach which would bypass the limitations of law enforcement.

Thus, on 2 April 2001 an Act entitled 'Amnesty for the Citizens of the Republic of Kazakhstan in connection with the laundering of money' was adopted into law, allowing for the exclusive one-time legalization of assets that were previously withdrawn from legal economic circulation and had not been declared for tax purposes, and which resulted from the perpetration of certain economic offenses. The Act proscribed a thirty-day period during which such funds could be transferred without the proper dispositions into special accounts held by second-tier banks, meaning that any deposits would be safeguarded by the banking sector's system of collective guarantee. Although the Act stipulated that the amnesty did not apply to the legalization of money derived from corruption offences, or offences against either the person, the constitution, national security, private property, public order, or public health and morals, as well as money belonging to others or received as loans, the reality was that the state had little capacity to effectively determine the origins of the money being legalized. And although this initial amnesty period was extended for a short while, the process did not bring significant inflows of funds into the national economy; approximately 70.5 billion KZT was leveraged (approximately $\$ 480$ million USD), of which $88.5 \%$ took the form of cash receipts (82\% in US dollars) and $11 \%$ ( $\$ 50.5$ million USD) non-cash deposit transfers from accounts held in foreign banks. The maximum individual amount legalized was $\$ 800,000$ USD cash, and the 
average deposit size was $\$ 164,000$ USD; some $70 \%$ of legalized assets were subsequently left on deposit in the banking system. ${ }^{6}$

Despite the limits of this first effort at legalization, it was deemed sufficiently successful to justify a second amnesty period, which would apply (unlike the first) to all property and assets held by individuals and legal entities, not just to money. An Act entitled 'Amnesty in connection with the legalization of property' was passed into law on July 5, 2006, intended to allow for the legalization of property derived from the commission of certain crimes and administrative offenses under the laws of the Republic of Kazakhstan. This amnesty, which lasted for a longer period than the first one, led to the legalization of property totalling 828 billion KZT (\$6.79 billion USD) in value, including cash to the value of 536 billion KZT ( $\$ 4.4$ billion USD). To contextualise, the equivalent of $8.7 \%$ of Kazakhstan's national GDP was legitimized via deposits made by $10 \%$ of the total population of the country. This made the second Kazakh amnesty highly successful by comparative standards; the most wellknown example of a previous amnesty of this sort was in Ireland in 1988, where the funds legitimized amounted to $2.5 \%$ of GDP. As well as the financial return associated with this amnesty, the process generated useful knowledge relating to the shadow economy and the illicit business practices that underpin it; most of the property legalized under the amnesties in 2001 and 2007 were acquired as a result of business corruption. ${ }^{7}$

\section{Conclusions}

The notion of 'amnesty' is compatible with a conception of money laundering that views the wrongfulness of the act as residing in remote economic harms that accrue to the financial system, rather than as a form of complicity in the predicate offence that generated the money (Alldridge 2008: 457). Such a conception reflects the approach originally taken in international money laundering circles. Seeing the harm caused by laundering in economic terms means that it is notionally possible, therefore, to measure that harm against a countervailing economic benefit, and determine that the legalization of illicit capital might produce benefits that outweigh

\footnotetext{
${ }^{6}$ This legalization was connected with the introduction of new tax code which significantly decreased value added tax from $20 \%$ to $16 \%$, and social tax from $26 \%$ to $21 \%$.

${ }^{7}$ http://www.rg.ru/Anons/arc 2001/0619/5.shtm
} 
those harms, and thus present a preferable option. For a country like Kazakhstan, this allowed for the recovery of significant funds to assist in the development of the legitimate economy. These funds bring back into mainstream circulation assets that would otherwise remain unusable, much of which passed into the hands of their current owners during the transition to independence. Amnesties thus contribute to the market-constituting aims of money laundering regimes, in that they expand the regulated space within which commerce can occur (Braithwaite 2008). Of course, the proposition that amnesties on the laundering of illicit money can be desirable must not be interpreted as an argument in favour of removing criminal law prohibitions on money laundering entirely; the need to enforce against recognised predicate offences, particularly those relating to serious and organised crime, requires that national legal systems have effective criminal offences, backed up with appropriately stringent monitoring systems. But the application of these measures in the context of a transitional state can entrench existing problems, maintaining the division between legitimate and illegitimate economies.

As such, there is a need to look beyond the crime control rationale to determine whether there are illegitimate assets within the shadow economy that merit recovery; funds that accrue from untaxed or informal work, proceeds acquired during the early days of independence, or assets deriving from unregulated or unofficial commerce, can all be constructively used within the legitimate economy. These forms of illegitimate property do not have the connection to an underlying serious predicate offence that would merit criminalisation according to the 'crime control' rationale. As such, it is harder to justify the blanket criminalisation of those resources. It is clear that Kazakhstan's desire to encourage inward investment and economic growth requires it to demonstrate that it has a robust financial system and takes active steps to prevent the permeation of the economy by organised crime. But there are also untapped funds within its borders, many of which remain inaccessible once antimoney laundering controls are put in place. These assets distort formal understandings of the state of the economy, and can lead to the pursuit of policy choices that are less than optimal. Kazakhstan's experience of an amnesty on the legalization of illegally acquired capital was that the shadow economy was weakened, there was a significant increase in investment in legitimate businesses, and the revenue that the state obtained from them was increased. Temporary 
amnesties can facilitate the constitution of the marketplace which anti-money laundering laws seek to protect, and used properly, can be a valuable policy choice for developing nations.

\section{References}

Alam, A. and Banerji, A. (2000), Uzbekistan and Kazakhstan: A Tale of Two Transition Paths, World Bank Policy Research Paper 2472, Washington, D.C.

Alldridge, P. (2008), 'Money Laundering and Globalization', Journal of Law and Society, 35/4: 437-463.

Braithwaite, J. (2008), Regulatory Capitalism: How it Works, Ideas for Making it Work Better, Cheltenham: Edward Elgar.

Cuéllar, M-F. (2003), 'The Tenuous Relationship Between the Fight Against Money Laundering and the Disruption of Criminal Finance', Journal of Criminal Law and Criminal Justice, 93/2: 311-466.

Darimbetov B.N. and Spanov M.U. (2001), The Shadow Economy in Kazakhstan: Sources and Mechanisms of Implementation, Moscow: Socis.

Dzhekebaev W.S. (2001), Basic Principles of Criminal Law of the Republic of Kazakhstan, Almaty: Zheti Zhargy.

Eilat, Y. And Zinnes, F. (2002), 'The Shadow Economy in Transition Countries: Friend or Foe? A Policy Perspective', World Development, 30/7: 1233-1254.

FATF (2011), Laundering the Proceeds of Corruption, (at http://www.fatfgafi.org/media/fatf/documents/reports/Laundering\%20the\%20Proceeds\%20of \%20Corruption.pdf).

FATF (2012), The FATF Recommendations: International Standards on Combating Money Laundering and the Financing Of Terrorism \& Proliferation, (at http://www.fatf-

gafi.org/media/fatf/documents/recommendations/pdfs/FATF\%20Recommenda tions\%20\%28approved\%20February\%202012\%29\%20reprint\%20May\%2020 12\%20web\%20version.pdf). 
Geiger, H. and Wuensch, O. (2007), 'The Fight against Money Laundering: An Economic Analysis of a Cost-benefit Paradoxon', Journal of Money Laundering Control, 10/1: 91-105.

Haller, M. H. (1990), 'lllegal Enterprise: A Theoretical and Historical Interpretation', Criminology, 28/2: 207-236.

Harvey, J. (2004), 'Compliance and Reporting Issues Arising for Financial Institutions from Money Laundering Regulations: A Preliminary Cost Benefit Study', Journal of Money Laundering Control, 7/4: 333-346.

International Monetary Fund [IMF] (2004), Republic of Kazakhstan: Financial System Stability Assessment-Update (Country Report 04/268), Washington, D. C.: IMF.

Iwasaki, I. and Suzuki, T. (2007), 'Transition Strategy, Corporate Exploitation, and State Capture: An Empirical Analysis of the Former Soviet States', Communist and Post-Communist Studies, 40/4: 393-422.

Kim, S-W. and Pridemore, W. (2005), 'Social Change, Institutional Anomie, and Serious Property Crime in Transitional Russia', British Journal of Criminology, 45/1: 81-97.

Kim, S-W. and Pridemore, W. (2006), 'Democratization and Political Change as Threats to Collective Sentiments: Testing Durkheim in Russia', The Annals of the American Academy of Political and Social Sciences, 605: 82-103.

Kulekeev Z. A. (1997), 'The Shadow Economy in Kazakhstan', paper presented at the Economic Development Institute Conference on "Understanding the Transition in Central Asia," Washington D.C., June 1997.

Levi, M. (2002), 'Money Laundering and its Regulation', The Annals of the American Academy of Political and Social Sciences, 582: 181-194.

Levi, M. and Gilmore, W. (2002), 'Terrorist Finance, Money Laundering and the Rise and Rise of Mutual Evaluation: a New Paradigm for Crime Control?', 4 European Journal of Law Reform, 4/2: 337-364. 
Levi, M. and Reuter P. (2006), 'Money Laundering', Crime \& Justice, 34: 289-375.

Nichols, P. M. (2001), 'The Fit Between Changes To The International Corruption Regime And Indigenous Perceptions Of Corruption In Kazakhstan', University of Pennsylvania Journal of International Economics and Law, 22/4: 863-973.

Olcott, M. B. (2010), Kazakhstan: Unfulfilled Promise?, Washington, D.C.: Carnegie Endowment for International Peace.

Reuter, P. and Truman, E. (2004), Chasing Dirty Money: The Fight Against Money Laundering, Washington, D.C.: Institute for International Economics.

Schneider, F. (2003), 'The Size and Development of the Shadow Economies and Shadow Economy Labor Force of 22 Transition and 21 OECD Countries: What Do We Really Know?', in Belev, B. (ed.), The Informal Economy in the EU Accession Countries: Size, Scope, Trends and Challenges to the Process of EU Enlargement, Sofia: Centre for the Study of Democracy, pp23-62.

Schneider, F. and Este, D. H. (2002), 'Shadow Economies: Size, Causes and Consequences', Journal of Economic Literature, 38/1: 77-114.

Seagrave, S. (1995), Lords of the Rim: The Invisible Empire of the Overseas Chinese, New York: Putnam's Sons. 